\section{Tryprostatins A and B, Novel Mammalian \\ Cell Cycle Inhibitors Produced by Aspergillus fumigatus}

Sir:

In the course of our screening for new inhibitors of mammalian cell cycle ${ }^{1)}$, we have discovered two novel compounds named tryprostatins A (1) and B (2) (Fig. 1), from the secondary metabolites of a marine fungal strain BM939. The producing strain was isolated from a sea sediment sample collected in the sea bottom $(760$ meters deep) of the mouth of Oi river, Sizuoka prefecture, Japan, and was identified as Aspergillus fumigatus through a taxonomic study. Here we preliminarily report the isolation, structures and biological activities of $\mathbf{I}$ and 2.
The producing strain was cultured in a 30 -liter jar fermenter containing 18 liters of fermentation medium (glucose $3 \%$, soluble starch $2 \%$, soybean meal $2 \%$, $\mathrm{K}_{2} \mathrm{HPO}_{4} 0.5 \%$ and $\mathrm{MgSO}_{4} \cdot 7 \mathrm{H}_{2} \mathrm{O} 0.05 \%$, adjusted at $\mathrm{pH} 6.5$ before sterilization) containing $0.05 \%$ of CA-123 and KM-68 antifoam, respectively. The fermentation was carried out for 72 hours at $28^{\circ} \mathrm{C}$ under the following condition; $350 \mathrm{rpm}$ stirring speed and 7 liters/minute aeration rate.

The fermentation and the following separation procedure were monitored by the inhibitory activity on the cell cycle progression of a mouse tsFT 210 cell line which is a temperature-sensitive $\mathrm{p} 34^{c d c 2}$ mutant. The cells were growing normally at $32^{\circ} \mathrm{C}$, but arrested in the $\mathrm{G} 2$ phase at $39^{\circ} \mathrm{C}^{1 \sim 31}$.

The cultured whole broth was centrifuged to separate

Fig. I. Structures of tryprostatins A (1) and B (2).<smiles>COc1ccc2c(CC3C(=O)C4CCCN4C3=O)c(CC=C(C)C)[nH]c2c1</smiles>

1<smiles>CC(C)=CCc1[nH]c2ccccc2c1CC1C(=O)N2CCCC2C(=O)N1C</smiles>

2

Fig. 2. Purification procedure for tryprostatins A (1) and B (2).

BM939 Whole Broth

(18 liters)

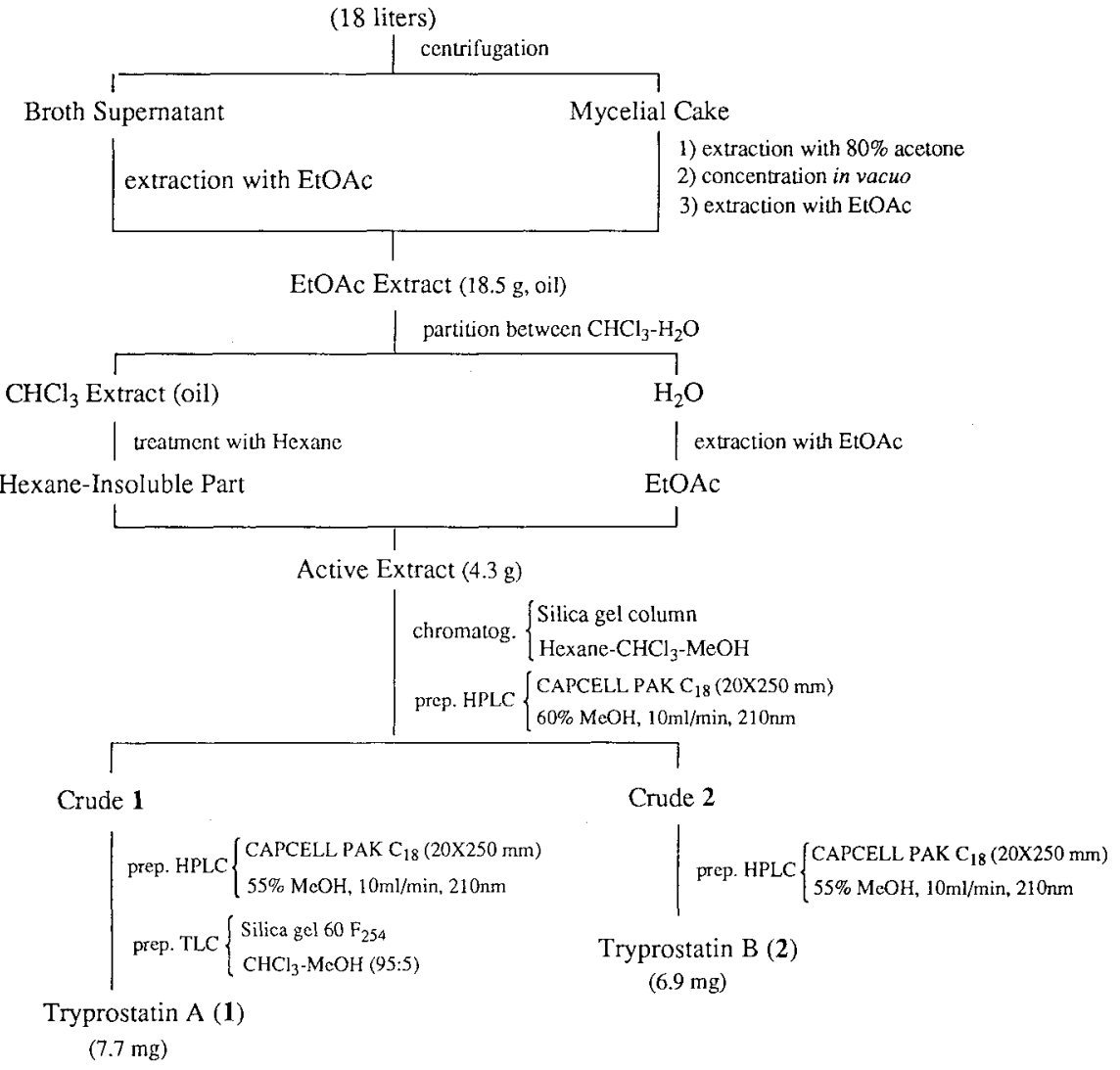


Table 1. Physico-chemical properties of tryprostatins A (1) and B (2).

\begin{tabular}{lll}
\hline Characteristics & \multicolumn{1}{c}{$\mathbf{1}$} & \multicolumn{1}{c}{$\mathbf{2}$} \\
\hline Appearance & Pale yellow crystalline solid & Pale yellow crystalline solid \\
MP & $120-123^{\circ} \mathrm{C}$ & $102-105^{\circ} \mathrm{C}$ \\
{$[\alpha]_{\mathrm{D}}^{27}$} & $-69.7^{\circ}\left(\mathrm{c} 0.70, \mathrm{CHCl}_{3}\right)$ & $-71.1^{\circ}\left(\mathrm{c} 0.63, \mathrm{CHCl}_{3}\right)$ \\
Molecular Formular & $\mathrm{C}_{22} \mathrm{H}_{27} \mathrm{~N}_{3} \mathrm{O}_{3}$ & \\
HR-EI-MS & $\mathrm{M}^{+}$ & $\mathrm{C}_{21} \mathrm{H}_{25} \mathrm{~N}_{3} \mathrm{O}_{2}$ \\
Found $(m / z)$ & 381.2050 & \\
Calcd $(m / z)$ & 381.2050 & $\mathrm{M}^{+}$ \\
& & 351.1943 \\
UV $\lambda_{\max }^{\mathrm{MeoH}} \mathrm{nm}(\varepsilon)$ & $227(24540)$ & 351.1944 \\
& $270(5450)$ & $226(23780)$ \\
& $297(6590)$ & $277(8690)$ \\
IR $v_{\max }^{\mathrm{KBr}} \mathrm{cm}{ }^{-1}$ & $3365,3270,3070$, & $298(\mathrm{sh}, 7180)$ \\
& $2965,2930,2880,2860$, & $2970,2930,2875,2860$, \\
& $1670,1655,1460$, & $1670,1655,1460$, \\
& 1430,1160 & 1435,1160 \\
\hline
\end{tabular}

Fig. 3. UV spectra of tryprostatins A (1) and B (2).

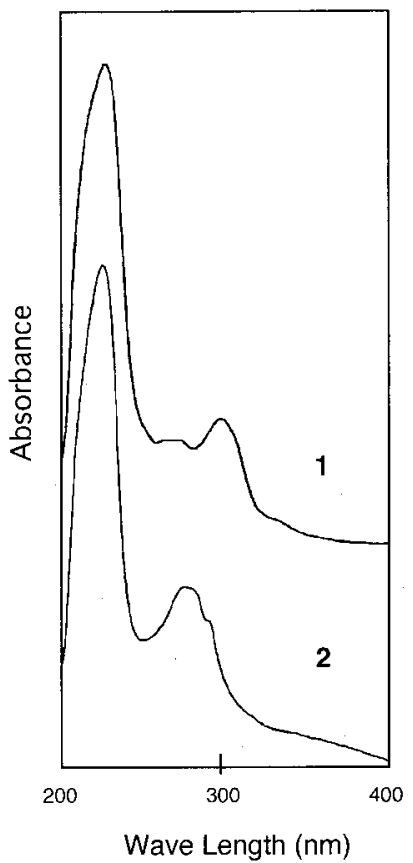

to a broth supernatant (18 liters) and a mycelial cake. The latter was extracted with $80 \%$ aqueous acetone which was evaporated in vacuo to remove acetone. Both the broth supernatant and the mycelium extract showed an inhibitory activity on the cell cycle progression of tsFT210 cells and thus both were extracted respectively with the same volume of EtOAc. The EtOAc solution obtained was combined and concentrated in vacuo to afford an oily extract ( $18.5 \mathrm{~g}$ ) which was further purified as shown in Fig. 2 to give an active extract $(4.3 \mathrm{~g})$. This extract was then separated by a combination of column
Fig. 4. IR spectra of tryprostatins A (1) and B (2).

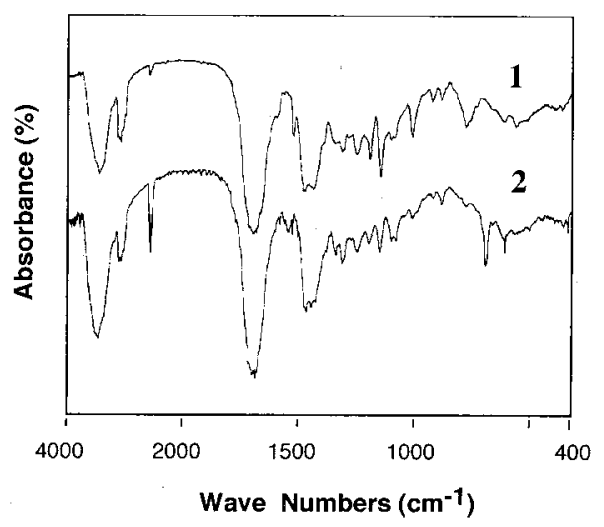

chromatography (silica gel 60, Merck), repeated HPLC (CAPCELL PAK $\mathrm{C}_{18}$, Shiseido) and preparative TLC (silica gel $60 \mathrm{~F}_{254}$ plate, Merck) to obtain $1(7.7 \mathrm{mg}$ ) and 2 (6.9 mg) (Fig. 2).

Tryprostatins A (1) and B (2) were obtained both as pale yellowed crystalline solids. The physico-chemical properties of 1 and 2 are summarized in Table 1. Their molecular formulae, $\mathrm{C}_{22} \mathrm{H}_{27} \mathrm{~N}_{3} \mathrm{O}_{3}$ for 1 and $\mathrm{C}_{21} \mathrm{H}_{25} \mathrm{~N}_{3} \mathrm{O}_{2}$ for 2, were determined by HR-EI-MS measurements (Found $m / z 381.2050\left(\mathrm{M}^{+}\right.$), Calcd for $\mathrm{C}_{22} \mathrm{H}_{27} \mathrm{~N}_{3} \mathrm{O}_{3}$ 381.2050 for 1; Found $m / z 351.1943\left(\mathrm{M}^{+}\right)$, Calcd for $\mathrm{C}_{21} \mathrm{H}_{25} \mathrm{~N}_{3} \mathrm{O}_{2} 351.1944$ for 2). The UV spectra (Fig. 3) of 1 and 2 respectively revealed the presence of a 6-O-methylindole chromophore in 1 with the absorption maxima at 227 ( $\varepsilon 24540), 270$ (5450) and $297 \mathrm{~nm}(6590)^{4)}$ and the presence of an indole chromophore in 2 with 226 (23780), $277(8690)$ and $298(\mathrm{sh}, 7180)^{5)}$. And their IR spectra closely resembled in the functional group region, as shown in Fig. 4. The multiple absorption at 
Fig. 5. Effects of 1 and 2 on cell cycle progression of tsFT210 cells.

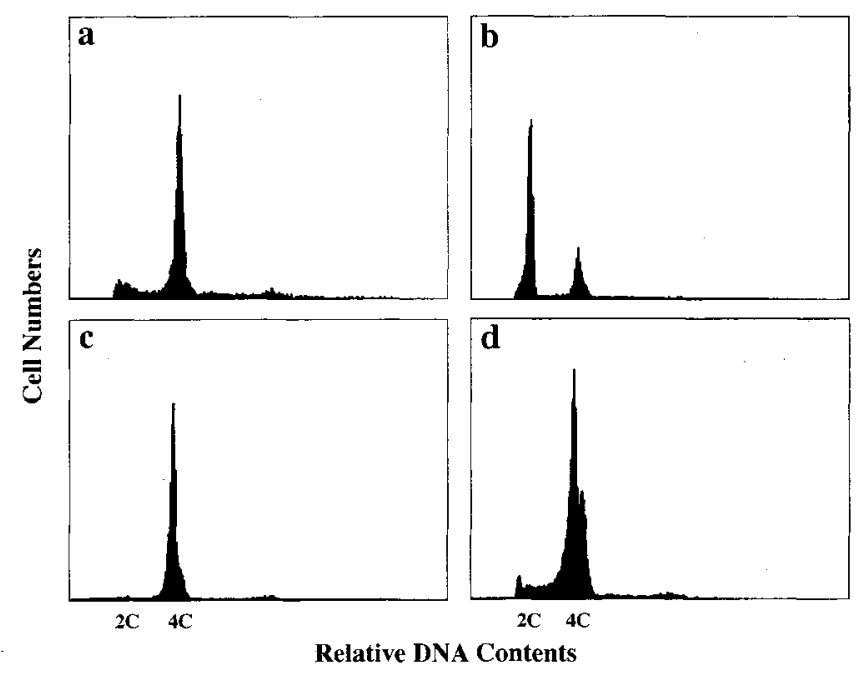

The tsFT210 cells were synchronized in the G2 phase by incubation at $39.4^{\circ} \mathrm{C}$ for 17 hours at a density of $2 \times 10^{5}$ cells $/ \mathrm{ml}$ in RPMI- 1640 medium supplemented with $5 \%$ calf serum. Then, the cells were maintained at $39.4^{\circ} \mathrm{C}$ up to 4 hours (a) or allowed to progress into mitosis at $32^{\circ} \mathrm{C}$ for 4 hours in the absence (b) or in the presence of tryprostatin A $(50 \mu \mathrm{g} / \mathrm{ml})$ (c) and tryprostatin B $(12.5 \mu \mathrm{g} / \mathrm{ml})$ (d), respectively.

1670 and $1655 \mathrm{~cm}^{-1}$ due to amide groups together with the absence of the amide II band near $1550 \mathrm{~cm}^{-1}$ suggest the presence of diketopiperazine system ${ }^{5 \sim 7}$ in both 1 and 2. Eventually, the structures of tryprostatins $A$ and $\mathrm{B}$ were determined as shown in Fig. 1 by detailed analyses of their ${ }^{1} \mathrm{H}$ and ${ }^{13} \mathrm{C}$ NMR spectra with the aid of 2D NMR techniques including field-gradient heteronuclear multiple-bond correlation (FG-HMBC) spectroscopy.

The molecules of $\mathbf{1}$ and $\mathbf{2}$ are composed from a 2isoprenyltryptophan moiety and a proline residue, forming a diketopiperazine unit, which are distinguished from the molecules of fumitremorgin series ${ }^{8)}$ in the respect of opening the centered heterocyclic ring at $\mathrm{C}-\mathrm{N}$ bond between 18 and 10 positions. Only few kinds of natural products structurally related to $\mathbf{1}$ and $\mathbf{2}$ such as deoxybrevianamide-E had so far been reported ${ }^{5)}$, and present result provides the first example of natural product belonging to this novel class as the inhibitor of mammalian cell cycle. Tryprostatins A and B may be shunt metabolites of verruculogen ${ }^{8)}$ and fumitremorgin series $^{8)}$ like as deoxybrevianamide- $\mathrm{E}$ in biogenesis of brevianamides ${ }^{7)}$.

Tryprostatins A (1) and B (2) completely inhibited cell cycle progression of tsFT 210 cells in the $\mathrm{G} 2 / \mathrm{M}$ phase at final concentrations of $50 \mu \mathrm{g} / \mathrm{ml}$ of 1 and $12.5 \mu \mathrm{g} / \mathrm{ml}$ of 2, respectively (Fig. 5). Further studies on their biological activities and mechanism of their action are currently undertaken.
Details of the structural and biological studies will be reported elsewhere.

Acknowledgments

We thank Ms. Tamiko ChiJmatsu (RIKEN) for the measurements of FG-HMBC spectra. This research was supported in part by a Grant from the Ministry of Education, Science and Culture, Japan and a Grant for "Biodesign Research Program" from RIKEN (C.-B. C. and H. O.).

\section{Cheng-Bin Cui \\ HIDEAKI KaKEYA \\ GEN OKADA \\ RIE ONOSE \\ Makoto Ubukata ${ }^{\dagger}$ \\ IsAMU TAKAHASHI ${ }^{\dagger \dagger}$ \\ KIYOSHI ISONO ${ }^{\dagger \dagger}$ \\ HiROYUKI OSADA*}

The Institute of Physical and Chemical Research (RIKEN),

Wako, Saitama 351-01, Japan

${ }^{\dagger}$ Biotechnology Research Center, Toyama Prefectural University,

Kosugi-machi, Imizu-gun, Toyama 939-03, Japan

${ }^{\dagger+}$ Central Research Laboratories

Kaken Pharmaceutical Co Ltd.,

Gensuke, Fujieda, Shizuoka 426, Japan

(Received July 20, 1995)

\section{References}

1) Osada, H.; F. Hanaoka, R. Onose, M. Inagaki \& K. IsONO: Screening of cell cycle inhibitors from microbial metabolites by a bioassay using a mouse cdc 2 mutant cell line, tsFT210. submitted to J. Antibiotics 1995

2) Mrneo, C.; Y. Murakami, Y. Ishimi, F. Hanaoka \& M.-A. YAMADA: Isolation and analysis of a mammalian temperature-sensitive mutant defective in $\mathrm{G} 2$ functions. Exp. Cell Res. 167: 53 62, 1986

3) Th'NG, J. P. H.; P. S. Wright, J. Hamaguchi, M. G. Lee, C. J. Norbury, P. Nurse \& E. M. Bradbury: The FT210 cell line is a mouse G2 phase mutant with a temperature-sensitive $C D C 2$ gene product. Cell 63: $313 \sim 324,1990$

4) Fayos, J.; D. Lokensgard, J. Clardy, R. J. Cole \& J. W. KIRKSEY: Structure of verruculogen, a tremor producing peroxide from Penicillium verruculosum. J. Am. Chem. Soc. 96: 6785 6787, 1974

5) STEYN, P. S.: The structures of five diketopiperazines from Aspergillus ustus. Tetrahedron 29: 107 120, 1973

6) Steyn, P. S.: Austamide, a new toxic metabolite from Aspergillus ustus. Tetrahedron Lett. 1971: $3331 \sim 3334$

7) Brich, A. J. \& J. J. Wright: Studies in relation to biosynthesis-XLII. The structural elucidation and some aspects of the biosynthesis of the brevianamide-A and -E. Tetrahedron 26: 2329 2344, 1970

8) Steyn, P. S. \& R. VleggaAR: Tremorgenic mycotoxins. Progress in the Chemistry of Organic Natural Products (Founded by L. Zechmiester, Edited by W. Herz, H. GrisebaCH and G. W. Kirby). 48: $1 \sim 80,1985$ 